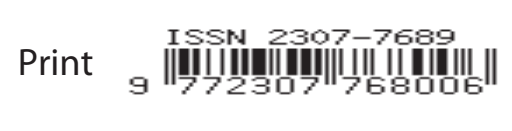

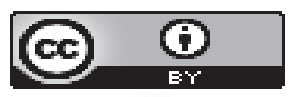

Online

ISSN $2616-6054$ 9 ||l||
Mediscope

ORIGINAL ARTICLE

\title{
Use of intra-urethral steroid clobetasol cream to prevent the recurrence of urethral stricture after optical urethrotomy: Randomized clinical trial
}

\author{
M Ahmed ${ }^{1}$, SM Hossain ${ }^{2}$, MT Islam³, G Kobir ${ }^{4}$, BK Basu ${ }^{5}$
}

\begin{abstract}
Background: One of the most frequently used treatments of urethral strictures is the optical internal urethrotomy (OIU). About $20 \%-60 \%$ of urethral stricture patients develop recurrent stricture after Urethrotomy. Glucocorticoids have proved anti-proliferative effect and thereby used to reduce the formation of scar tissue. In urethral stricture, the main pathology is scar tissue formation. Objective: The aim of this study is to see the influence the local application of steroid clobetasol cream after Urethrotomy. Method: Between January to December 2016, all Bulbar urethral stricture patients attended to the hospital and private clinics, were included in this study. They were placed in two groups alternatively. They underwent standard OIU. First group (35 patients) offered clean intermittent self-catheterization (CISC) postoperatively without any steroid cream in urethra. The second group (35 patients) practiced CISC in the same way but used clobetasol cream with catheter. Both groups used topical anaesthesic Lidocain HCL for lubrication of urethra. Result: No patient developed recurrence with clobetasol cream after 3 months, but two patients developed recurrence without steroid. At 6 months, this result is $6(17.14 \%)$ and $10(28.57 \%)$ accordingly. Conclusion: Topical steroid clobetasol cream reduces urethral stricture recurrence.
\end{abstract}

Key word: Urethral stricture recurrence, Clobetasol cream.

\section{Introduction:}

Urethral stricture is relatively common problem that we encounter in urological practice. As urethral stricture causes progressive narrowing of the urethral lumen, signs and symptoms of urinary obstruction arise. These patients experience obstructive symptoms like poor stream, straining to urinate, incomplete voiding, end dribbling, urinary retention and recurrent urinary tract infections. ${ }^{1}$ Internal urethrotomy is a safe first-line treatment for urethral strictures independent of etiology and location, with an overall primary success rate of $60-70 \%$. Internal urethrotomy is usually indicated for strictures that are located in the bulbar urethra and are less than $1.5 \mathrm{~cm}$ in length, with minimal spongiofibrosis. ${ }^{2}$ Urethroplasty has a much higher chance of success (85-90\%) and is considered the gold-standard treatment. 3 The most common etiology is idiopathic in developed countries and trauma in develop

1. M Ahmed, Assistant Professor, Department of Urology, Khulna Medical College, Khulna.

2. SM Hossain, Associate Professor, Department of Surgery, Khulna Medical College, Khulna.

3. MT Islam, Assistant Professor, Department of Burn \& Plastic Surgery, Khulna Medical College, Khulna.

4. G Kobir, Assistant Professor, Department of Urology, Khulna Medical College, Khulna.

5. BK Basu, Associate professor, Department of Surgery, Gazi Medical, Khulna. 
ing countries. ${ }^{4}$ latrogenic injuries, such as oversized resectoscope at the time of transurethral surgery and traumatic placement of indwelling urinary catheters, account for 45 percent of all cases. ${ }^{5}$ Urethral stricture is one of the most difficult urological problems to heal adequately and many surgical and non surgical techniques have been described to its management. ${ }^{6}$ The use of various antifibrotic substances during the endoscopic procedure have also been describe by many authors - corticosteroids, botulinum toxin, hyaluronic acid, captopril gel and mitomycin C among others. ${ }^{7}$ Urethral stricture disease has always been a challenge for urologists. Different treatment modalities that are used for treatment of urethral stricture disease are dilatation, urethrotomy, stent placement, and urethroplasty. Steenkamp et al. have found no significant difference in efficacy between dilation and internal urethrotomy as initial treatment of strictures. ${ }^{8}$

The male anterior urethra stricture (US) is characterized by a fibrotic process which achieves varying degrees of peri-urethral spongiosum tissue fibrosis (spongiofibrosis) associated with a decrease in urethral caliber and consequently in the urine flow. Endoscopic treatment is based on the deep incision of the fibrotic area and subsequently local reepithelization process to the maintenance of the urethral patency. ${ }^{9}$

Management of US is a challenge for Urologists. Different modalities of treatment -used for Urethral Stricture disease are Dilatation, Urethrotomy (OIU) and Urethroplasty. Recurrent Urethral Stricture is most common late post-operative complication. Low success rate and high recurrence rate encouraged the urologists to use different adjuvant agents. The agents used to reduce US recurrence are intralesional steroid injection (triamcinolone acetate), Hyaluronidase and Mitomycin C. Although, intralesional steroid injection has been shown to provide good results after Urethrotomy, but it is difficult to inject steroid intralesionally. It needs help of doctor every time. But clean intermittent self catheterization (CISC) is common practice after Urethrotomy and performed by the patient himself. Few study has evaluated the efficacy of tropical steroid clobetasol cream after urethrotomy (OIU).

\section{Methods:}

The study conducted at Khulna Medical College Hospital and some private hospitals of Khulna and Dhaka.

Study Design: Randomized clinical trial.

Study period: January 2016 to December 2016 (total 12 months).

Study population includes urethral stricture (US) which is less than $2 \mathrm{~cm}$ in length. The stricture length was measured by both preoperative retrograde-urethrogram and endoscopic evaluation.

Exclusion criteria: $>2 \mathrm{~cm}$ stricture, postTURP US, neurogenic bladder with US, associated Balanitis Xerotica Obliterance (BXO), previous OIU or dilatation and patients with previous corticosteroid therapy were excluded from this study.

Pre-operative Evaluation: All patients were evaluated by details history, physical examination, Retrograde urethrogram (RGU) and urethroscopy. Pre-operative antibiotic Ceftriaxazone 1gm daily injected half an hour before OIU. A glide wire (0.035") passed through the narrow lumen under spinal anaesthesia. Using cold knife -incision was made only at $12 \square$ clock position of stricture site to avoid spongio-cavernous fistula. Only fibrous tissue was cut, normal healthy urethra remained intact. 16fr Foly Bardia catheter kept in situ for 7days. After removal of catheter patients were followed up after 1 month, 3 months and 6 months.

Patients were placed in two groups. Every Odds (Group-A) selected for tropical clobetasol cream (Clovate.05\% cream, ACl pharmaceuticals) with $14 \mathrm{fr}$ Nelaton catheter during clean intermittent self-catheterization (CISC) 
and Lidocaine HCL jelly in the urethra. Every even numbers (Group-B), in which patients have not given clobetasol cream to lubricate the catheter, but used tropical anaestia Lidocain $\mathrm{HCL}$ jelly in urethra to lubricate. The schedule of CISC was twice a week for six months with $14 \mathrm{fr}$ Nelaton Catheter. Patients were followed with history, physical examination, urinalysis and Uroflowmetry at 1 month, 3 month and 6 month. Uroflow pattern assured for improvement of flow pattern after OIU. Flow rate $<10 \mathrm{ml} / \mathrm{sec}$ with bothersome symptoms should suspect for recurrence and confirmed with Retrograde Urethrogram (RGU) and Urethroscopy. Recurrence was defined as a need for repeat of surgical intervention during the follow-up period.

Result:

Number of patients underwent OIU $=81$. Of them 11 patients lost from follow-up. Each group has 35 patients.

Table 1: Age distribution of the patients

\begin{tabular}{|c|c|c|c|}
\hline & $\begin{array}{c}\text { Group A } \\
(n=35)\end{array}$ & $\begin{array}{c}\text { Group B } \\
(n=35)\end{array}$ & \multirow[t]{2}{*}{$P$ value } \\
\hline & Mean $\pm S D$ & Mean $\pm S D$ & \\
\hline $\begin{array}{l}\text { Age (years) } \\
\text { Range (min- } \\
\text { max) }\end{array}$ & $\begin{array}{c}30.4 \pm 17.2 \\
16-60\end{array}$ & $\begin{array}{c}34.1 \pm 15.9 \\
20-70\end{array}$ & 0.353 \\
\hline
\end{tabular}

Mean age was found $30.4 \pm 17.2$ years in group $A$ and $34.1 \pm 15.9$ years in group $B$. The difference was not statistically significant $(p>0.05)$ between two groups.

Table 2: Pre-operative maximum flow rate (Q-max) of the patients

\begin{tabular}{|c|c|c|c|}
\hline & $\begin{array}{c}\text { Group A } \\
(n=35)\end{array}$ & $\begin{array}{c}\text { Group B } \\
(n=35)\end{array}$ & \multirow[t]{2}{*}{$P$ value } \\
\hline & Mean $\pm S D$ & Mean $\pm S D$ & \\
\hline $\begin{array}{l}\text { Q-max } \\
\text { (ml/sec) }\end{array}$ & $6.1 \pm 1.1$ & $6.3 \pm 1.0$ & 0.429 \\
\hline $\begin{array}{l}\text { Range (min- } \\
\text { max) }\end{array}$ & $4.8-7.2$ & $5.1-7.3$ & \\
\hline
\end{tabular}

Mean pre-operative maximum flow rate was found $6.1 \pm 1.1 \mathrm{ml} / \mathrm{sec}$ in group $A$ and $6.3 \pm 1.0$ $\mathrm{ml} / \mathrm{sec}$ in group $B$. The difference was not statistically significant $(p>0.05)$ between two groups.
Table 3: Length of stricture of the patients

\begin{tabular}{|l|cc|cc|c|}
\hline $\begin{array}{l}\text { Length of } \\
\text { stricture } \\
(\mathbf{c m})\end{array}$ & $\begin{array}{c}\text { Group A } \\
(\mathbf{n}=\mathbf{3 5 )}\end{array}$ & $\begin{array}{c}\text { Group B } \\
(\mathbf{n}=\mathbf{3 5})\end{array}$ & $\begin{array}{c}\mathbf{P} \\
\text { value }\end{array}$ \\
\cline { 2 - 4 } & $\mathbf{n}$ & $\mathbf{\%}$ & $\mathbf{n}$ & $\mathbf{\%}$ & \\
\hline$<1$ & 20 & 57.1 & 21 & 60.0 & \\
$1-1.5$ & 11 & 31.4 & 10 & 28.6 & 0.965 \\
$<2$ & 4 & 11.4 & 4 & 11.4 & \\
\hline
\end{tabular}

Majority $(57.1 \%)$ patients was found with length of stricture $<1 \mathrm{~cm}$ in group $A$ and $21(60.0 \%)$ in group B. The difference was not statistically significant $(p>0.05)$ between two groups.

Table 4: Post-operative Q-max in different follow up

\begin{tabular}{|c|c|c|c|}
\hline \multirow[t]{2}{*}{$\begin{array}{l}\text { Q-max } \\
(\mathrm{ml} / \mathrm{sec})\end{array}$} & $\begin{array}{c}\text { Group A } \\
(n=35)\end{array}$ & $\begin{array}{c}\text { Group B } \\
(n=35)\end{array}$ & \multirow[t]{2}{*}{$\begin{array}{c}P \\
\text { value }\end{array}$} \\
\hline & Mean士SD & Mean士SD & \\
\hline & $24.0 \pm 11.1$ & $23.4 \pm 10.9$ & 0.820 \\
\hline 3 months & $22.0 \pm 9.1$ & $18.2 \pm 9.0$ & 0.084 \\
\hline 6 months & $17.4 \pm 9.2$ & $14.0 \pm 8.8$ & 0.119 \\
\hline
\end{tabular}

At 1 month, mean post-operative maximum flow rate was found $24.0 \pm 11.1 \mathrm{ml} / \mathrm{sec}$ in group A and $23.4 \pm 10.9 \mathrm{ml} / \mathrm{sec}$ in group B. At 3 month, mean post-operative maximum flow rate was found $22.0 \pm 9.1 \mathrm{ml} / \mathrm{sec}$ in group $A$ and $18.2 \pm 9.0 \mathrm{ml} / \mathrm{sec}$ in group B. At 6 month, mean post-operative maximum flow rate was found $17.4 \pm 9.2 \mathrm{ml} / \mathrm{sec}$ in group $A$ and $14.0 \pm 8.8 \mathrm{ml} / \mathrm{sec}$ in group $B$. The difference were not statistically significant $(p>0.05)$ between two groups.

Table 5: Recurrence of stricture of the study patients

\begin{tabular}{|c|c|c|c|c|c|}
\hline \multirow[t]{2}{*}{$\begin{array}{l}\text { Recurrence } \\
\text { of stricture }\end{array}$} & \multicolumn{2}{|c|}{$\begin{array}{c}\text { Group A } \\
(n=35)\end{array}$} & \multicolumn{2}{|c|}{$\begin{array}{c}\text { Group B } \\
(n=35)\end{array}$} & \multirow[t]{2}{*}{$\begin{array}{c}P \\
\text { value }\end{array}$} \\
\hline & $\mathrm{n}$ & $\%$ & $\mathrm{n}$ & $\%$ & \\
\hline 3 months & 0 & 0.0 & 2 & 5.71 & \\
\hline 6 months & 6 & 17.14 & 8 & 22.86 & \\
\hline Total & 6 & 17.14 & 10 & 28.57 & 0.254 \\
\hline
\end{tabular}

Six $(17.14 \%)$ patients had recurrence of stricture in group A and $10(28.57 \%)$ in group B. The difference was not statistically significant $(p>0.05)$ between two groups. 
Discussion:

In this study observed mean age was found $30.4 \pm 17.2$ years in group $A$ and $34.1 \pm 15.9$ years in group $B$. The difference was not statistically significant $(p>0.05)$ between two groups. Gupta et al.2 reported that the median (range) age of the patients was 37.4 (18-73 years). Kumar et al showed median age at presentation was 47 years $(17-80$ years).

In this study mean pre-operative maximum flow rate was found $6.1 \pm 1.1 \mathrm{ml} / \mathrm{sec}$ in group $A$ and $6.3 \pm 1.0 \mathrm{ml} / \mathrm{sec}$ in group $B$. The difference was not statistically significant $(p>0.05)$ between two groups. Gupta et al.2 reported median preoperative maximum flow rate on uroflowmetry was $7.7 \mathrm{~mL} / \mathrm{sec}$.

In current study observed majority $(57.1 \%)$ patients was found length of stricture $<1 \mathrm{~cm}$ in group A and $21(60.0 \%)$ in group B. The difference was not statistically significant $(p>0.05)$ between two groups. Kumar et al.7 in 2012 studied 50 patients with urethral stric $\neg$ tures $<3 \mathrm{~cm}$ treated with Holmium laser with intralesional triาamcinolone $(80 \mathrm{mg})$ under spinal anesthesia. Kumar et al.7 reported of these 103 patients, $80(77.66 \%)$ had bulbar urethral stricture, $7(6.8 \%)$ had pendular urethral stricture, and $16(15.5 \%)$ patients had pananterior urethral stricture. Modh et al.10 observed average stricture length was found $2.2 \mathrm{~cm}$ in failure group and $1.7 \mathrm{~cm}$ in success group. The difference was not statistically significant $(p>0.05)$ between two groups.

In this study showed at 1 month, mean postoperative maximum flow rate was found $24.0 \pm 11.1 \mathrm{ml} / \mathrm{sec}$ in group $A$ and $23.4 \pm 10.9$ $\mathrm{ml} / \mathrm{sec}$ in group B. At 3 month, mean postoperative maximum flow rate was found $22.0 \pm 9.1 \mathrm{ml} / \mathrm{sec}$ in group $A$ and $18.2 \pm 9.0$ $\mathrm{ml} / \mathrm{sec}$ in group B. At 6 month, mean postoperative maximum flow rate was found $17.4 \pm 9.2 \mathrm{ml} / \mathrm{sec}$ in group $A$ and $14.0 \pm 8.8$ $\mathrm{ml} / \mathrm{sec}$ in group B. The difference were not statistically significant $(p>0.05)$ between two groups. Gupta et al.2 reported the median postop erative maximum flow rates as recorded on uroflowmetry in the deflazocort group were 26.2, 22.3 and $18.2 \mathrm{~mL} / \mathrm{sec}$ at 1 , 3 and 6 months, respectively. The mean postoperative maximum flow rates as recorded on uroflowmetry in the control group were 24.4, 17.1 and $13.7 \mathrm{~mL} / \mathrm{sec}$ at 1,3 and 6 months, respectively.

In this study six (17.14\%) patients had recurrence of stricture in group $A$ and $10(28.57 \%)$ in group $B$. The difference was not statistically significant $(p>0.05)$ between two groups. Gupta et al. reported in the deflazocort group, 7 patients had recurrences (none of them at 1. and 3. Post-procedural months, but all of them at 6 months). In the control group, 13 patients had recur-rences (none at 1 month, 4 at 3 months and 9 at 6 months). Kumar et al.11 reported that the overall recur 7 rence rate was $24 \%$. The success rate in patients with strictures less than $1 \mathrm{~cm}$ in length was $95.8 \%$, whereas that in patients with strictures of 1 to $3 \mathrm{~cm}$ in length it was $57.7 \%$. Kumar et al.7, to assess the efficacy of OIU combined with intralesional injection of Triinject and it was found that success rate increased from $80.6 \%$ to $94.2 \%$ for shortsegment anterior urethral strictures. Kumar et al.7 reported Recurrence was noted in 12 patients out of 34 and in 15 patients out of 36 in control group. No statistically significant difference was noted in recurrence rate $(\square=$ 0.584 ) but time to recurrence decreased significantly in experimental group $(8.08 \pm 5.55$ versus $3.6 \pm 1.59$ months) $(\square<0.05) .12 \mathrm{In}$ older series, the primary success rate of internal urethrotomy alone is around $60-70 \% .13$ Modh et al.10 their cohort only experienced a recurrence rate of $29 \%$ with 20 months of follow-up.

\section{Conclusion:}

Use of tropical clobetasol cream may reduce urethral stricture recurrence after optical internal urethrotomy.

Limitations \& Recommendations: Small group of study population and short followup. Proper randomization not followed. Large 
group multi-centered randomized controlled trial with long follow-up is recommended.

\section{References:}

1. KC SR, Timilsina BR, Devkota G, Pradhan S, Lamsal S, Lamichanne N. Resection Urethroplasty for Urethral Stricture: Preliminary Findings from a Tertiary Care Hospital of Central Nepal. JCMS Nepal. 2019;15(1):1-4

2. Gupta S, Roy S, Pal DK. Efficacy of oral steroids after optical internal urethrotomy in reducing recurrence of urethral strictures. Turk J Urol 2018; 44(1): 42-4.

3. Gallegos MA and Santucci RA. Advances in urethral stricture management [version 1; referees: 4 approved] F1000Research 2016;5:1-9

4. Wessells $\mathrm{H}$, Angermeier KW, Elliott $\mathrm{S}$, et al. Male Urethral Stricture: American Urological Association Guideline. J Urol 2017; 197:182.

5. Lumen N, Hoebeke P, Willemsen P, et al. Etiology of urethral stricture disease in the 21st century. J Urol 2009; 182:983.

6. Jain SK, Kaza RC, Singh BK. Evaluation of holmium laser versus cold knife in optical internal urethrotomy for the management of short segment urethral stricture. Urol Ann. 2014;6:328-33.

7. Zhang K, Qi E, Zhang $Y$, Sa Y, Fu Q. Efficacy and safety of local steroids for urethra strictures: a systematic review and metaanalysis. $\mathrm{J}$ Endourol. 2014;28:962-8
8. Kumar S, Garg K, Singh SK, Mandal AK. Efficacy of optical internal urethrotomy and intralesional injection of Vatsala-

Santosh PGI Tri-inject (triamcinolone, mitomycin $\mathrm{C}$ and hyaluronidase) in the treatment of anterior urethral stricture. Adv Urol 2014; 2014: 1-4.

9. Cavalcanti AG and Fiedler G. Substitution urethroplasty or anastomotic urethroplasty for bulbar urethra strictures? Or endoscopic urethrotomy? BJU.2015.04.03

10. Modh R, Cai PY, Sheffield A, Yeung LL. Outcomes of Direct Vision Internal Urethrotomy for Bulbar Urethral Strictures: Technique Modification with High Dose Triamcinolone Injection. Advances in Urology, 2015; 2015: 1-5.

11. Kumar S, Kapoor A, Ganesamoni R, Nanjappa B, Sharma V, Mete UK. Efficacy of holmium laser urethrotomy in combination with intralesional triamcinolone in the treatment of anterior urethral stricture. Korean J Urol 2012;53:614-8.

12. Tabassi KT, Yarmohamadi A, Mohammadi S. Triamcinolone injection following internal urethrotomy for treatment of urethral stricture. Urology Journal, 2011; 8(2): 132-136.

13. Albers $P$, Fitchner J, Bruhl P, Muller SC. Long term results of internal urethrotomy. The Journal of Urology, 1996; 156: 1611-1614. 